\title{
THE CONCEPT OF RISK TOLERABILITY MATRIX DETERMINATION FOR AERONAUTICAL DATA AND INFORMATION CHAIN
}

\section{KONCEPCJA WYZNACZENIA MACIERZY TOLERANCJI RYZYKA DLA LAŃCUCHA DANYCH I INFORMACJI LOTNICZYCH}

\author{
Ewa Dudek, Michał Kozłowski \\ Warsaw University of Technology, Faculty of Transport \\ Politechnika Warszawska, Wydział Transportu
}

\begin{abstract}
This article is a continuation of the Authors' study on the ways to ensure the quality and safety of aeronautical data and information in the entire process (considered as the supply chain) of those data and information creation, collection, processing and publication. In its content attention was paid to air traffic proactive safety management a well as the need to manage identified incompatibilities. The risk assessment and tolerability matrices arising from ICAO specifications were presented, and then on their bases, the concept of such matrices determination for aeronautical data and information chain was developed. In addition, the criteria for consequences'leffects' of incompatibilities appearance assessment related strictly to air transport were elaborated. In the summary directions for further analysis were pointed out, leading to carrying out a full risk assessment analysis of the discussed chain with the use of the FMEA method.
\end{abstract}

Keywords: aeronautical data and information chain, risk tolerability matrix

Streszczenie: Artykut stanowi kontynuacje prac Autorów nad zagadnieniem sposobu zapewnienia jakości $i$ bezpieczeństwa danych i informacji lotniczych $w$ catym procesie (rozpatrywanym jako tańcuch dostaw) ich tworzenia, gromadzenia, przetwarzania $i$ publikacji. W jego treści zwrócono uwage na proaktywne zarzadzanie bezpieczeństwem $w$ ruchu lotniczym oraz konieczność zarzadzania zidentyfikowanymi niezgodnościami. Przedstawiono macierze oceny $i$ tolerancji ryzyka zawarte $w$ specyfikacjach ICAO, a następnie na ich podstawie opracowano koncepcje wyznaczenia takich macierzy dla tańcucha danych $i$ informacji lotniczych. Ponadto opracowano kryteria oceny konsekwencji/skutków wystapienia niezgodności $w$ odniesieniu bezpośrednio do transportu lotniczego. $W$ podsumowaniu wskazano kierunki dalszych prac, prowadzacych do przeprowadzenia petnej analizy oceny ryzyka omawianego tańcucha metoda FMEA.

Stowa kluczowe: lańcuch danych i informacji lotniczych, macierz tolerancji ryzyka 
The concept of risk tolerability matrix determination for aeronautical data... Koncepcja wyznaczenia macierzy tolerancji ryzyka dla tańcucha danych...

\section{THE CONCEPT OF RISK TOLERABILITY MATRIX DETERMINATION FOR AERONAUTICAL DATA AND INFORMATION CHAIN}

\section{Introduction}

According to civil aviation safety management standards, in particular those related to Safety Management System - SMS [10], this management should be systematic, explicit and proactive. At the present stage of considerations special attention is paid to the last feature. Proactive safety management is built upon an approach that emphasizes hazard identification and safety risk control and mitigation, before events that affect safety occur. Error and incompatibilities' capturing and early detection as well as prevention of their consequences before they occur, are the basis for the required approach. As stated in [6], "identifying future threats is to be a much more effective form of management than corrective and remedial action (so-called reactive approach) when adverse events have already taken place, and consequently their effects cannot be reversed".

This article is a continuation of the Authors' study on the ways to ensure the quality and safety of aeronautical data and information in the entire process (considered as the supply chain) of those data and information creation, collection, processing and publication. In previous publications $[1,2,4]$ the requirements, procedures and rules being in force in civil aviation and aiming at the assurance of the adequate level of safety in air operations were discussed. As the efficiency and effectiveness of air transport strongly depend on the provision of adequate quality information, a comprehensive and systematic approach to data quality assurance was proposed (for example in [2,3]) at all stages of the aeronautical data and information chain.

This publication focuses on the proactive approach to air traffic safety management, and taking into account the requirements of the polish National Safety Program In Civil Aviation [6] published in August 2016 and the described need to implement the Compliance Monitoring System (CMS), based on the principles related to Quality Management System (QMS) and its integration with the SMS system, with respect to analysed aeronautical data and information chain it was ascertained that each detected incompatibility should be managed. This process, in Authors' opinion, should begin with the determination of risk assessment and tolerability matrices related to error/incompatibility appearance in aeronautical data and information chain, which will allow risk assessment in the future and (what is so important in the safety management process) proactive error capturing and management of detected nonconformities. 


\section{Risk assessment}

According to State Safety Programme in Civil Aviation (pol. Krajowy Program Bezpieczeństwa w Lotnictwie Cywilnym - KPBwLC) [6] risk management consists of the two following areas:

- processes of threats identification,

- processes of risk assessment and mitigation.

To better understand the general concept of risk and more specific of safety risk the following definitions coming from the basic ICAO safety documents were used:

Risk [10] - the consequence of a hazard expressed by a measure of probability and/or frequency of occurrence.

Safety risk [10] is defined as an assessment, expressed in the predicted probability and severity of the consequences of the threat, taking as the reference the worst predictable situation.

Safety risk management [10] however, is a general term including safety risk assessing and mitigation in an organization to a level as low as reasonably practicable - ALARP.

In the risk evaluation process three risk regions were identified in the risk evaluation process: acceptable $-\mathrm{A}$, tolerable $-\mathrm{T}$ and intolerable (unacceptable) NA. The visual representation of the safety risk management process is the triangle in an inverted position (figure 1).
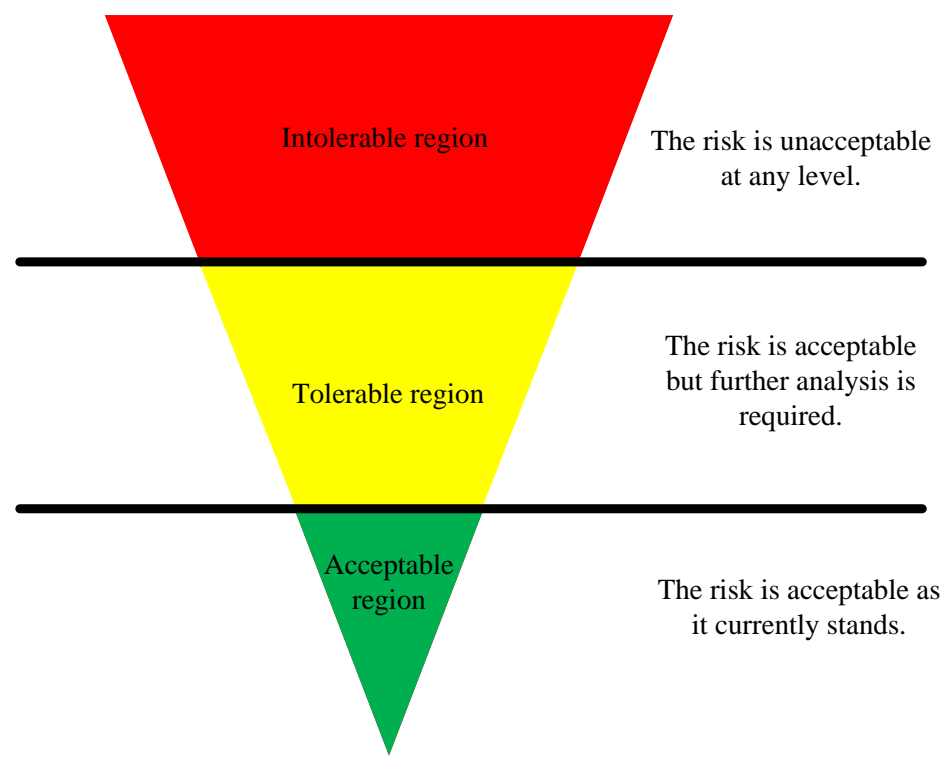

Fig. 1 Risk regions in safety risk management (own work based on [10]) 
The concept of risk tolerability matrix determination for aeronautical data... Koncepcja wyznaczenia macierzy tolerancji ryzyka dla łańcucha danych...

The conducted study of Safety Management Manual, ICAO Doc. 9859 [10] as well as Annex 19 to the Convention on Civil Aviation - Safety Management [16] leads to the conclusion that safety risk in Air Traffic Management system is expressed as a combination of the two following values: the probability and the effect (severity) of an event.

where:

$$
R=P \times S,
$$

$R$ - safety risk level,

$P-$ the probability of hazard's occurrence,

$S$ - the effects of hazard's occurrence.

Such approach makes risk assessment against the consequences of a hazard, if its destructive potential is revealed during the operation, possible to be carried out. Manual [10] proposes the following criteria for estimating the risk occurrence probability (Table 1), the severity of an event (Table 2) and risk evaluation (tolerability) criteria (Table 3):

Tab. 1 Safety risk probability matrix (based on [10])

\begin{tabular}{|c|c|c|}
\hline PROBABILITY & VALUE & MEANING \\
\hline Frequent & 5 & $\begin{array}{l}\text { Likely to occur many times/has occurred } \\
\text { frequently }\end{array}$ \\
\hline Occasional & 4 & $\begin{array}{l}\text { Likely to occur sometimes/has occurred } \\
\text { infrequently }\end{array}$ \\
\hline Remote & 3 & Unlikely to occur but possible/has occurred rarely \\
\hline Improbable & 2 & $\begin{array}{l}\text { Very unlikely to occur/not known to have } \\
\text { occurred }\end{array}$ \\
\hline $\begin{array}{l}\text { Extremely } \\
\text { improbable }\end{array}$ & 1 & Almost inconceivable that the event will occur \\
\hline
\end{tabular}

Tab. 2 Safety risk severity table (based on [10])

\begin{tabular}{|c|c|c|}
\hline $\begin{array}{l}\text { SEVERITY OF } \\
\text { OCCURRENCE }\end{array}$ & VALUE & MEANING \\
\hline Catastrophic & 5 & $\begin{array}{l}\text { Huge safety threat - multiple deaths, equipment } \\
\text { destroyed }\end{array}$ \\
\hline Hazardous & 4 & $\begin{array}{l}\text { Serious safety threat - serious injuries, major } \\
\text { equipment damage }\end{array}$ \\
\hline Major & 3 & $\begin{array}{l}\text { Significant safety threat - serious incident, } \\
\text { injury to persons }\end{array}$ \\
\hline Minor & 2 & $\begin{array}{l}\text { Inconsiderable influence on safety }- \text { minor } \\
\text { incident, operating limitations, use of emergency } \\
\text { procedures }\end{array}$ \\
\hline Negligible & 1 & No influence on safety - little consequences \\
\hline
\end{tabular}


Tab. 3 Safety risk tolerability matrix (based on [10])

\begin{tabular}{|lc|c|c|c|c|c|}
\hline \multirow{2}{*}{ Risk probability } & \multicolumn{5}{|c|}{ Risk severity } \\
\cline { 2 - 7 } & & $\begin{array}{c}\text { Catastr. } \\
5\end{array}$ & $\begin{array}{c}\text { Hazard. } \\
4\end{array}$ & $\begin{array}{c}\text { Major } \\
3\end{array}$ & $\begin{array}{c}\text { Minor } \\
2\end{array}$ & $\begin{array}{c}\text { Neglig. } \\
1\end{array}$ \\
\hline Frequent & 5 & NA & NA & NA & T & T \\
\hline Occasional & 4 & NA & NA & T & T & T \\
\hline Remote & 3 & NA & T & T & T & A \\
\hline Improbable & 2 & T & T & T & A & A \\
\hline $\begin{array}{l}\text { Extremely } \\
\text { improbable }\end{array}$ & 1 & A & A & A & A & A \\
\hline
\end{tabular}

\section{Aeronautical data and information chain}

The main idea of the aeronautical data and information chain is described in more details in Authors' previous works (for example in $[3,4]$ ), stating that this chain represents the consecutive steps of aeronautical data and information production and processing, from data request and derivation till their final use (figure 2).

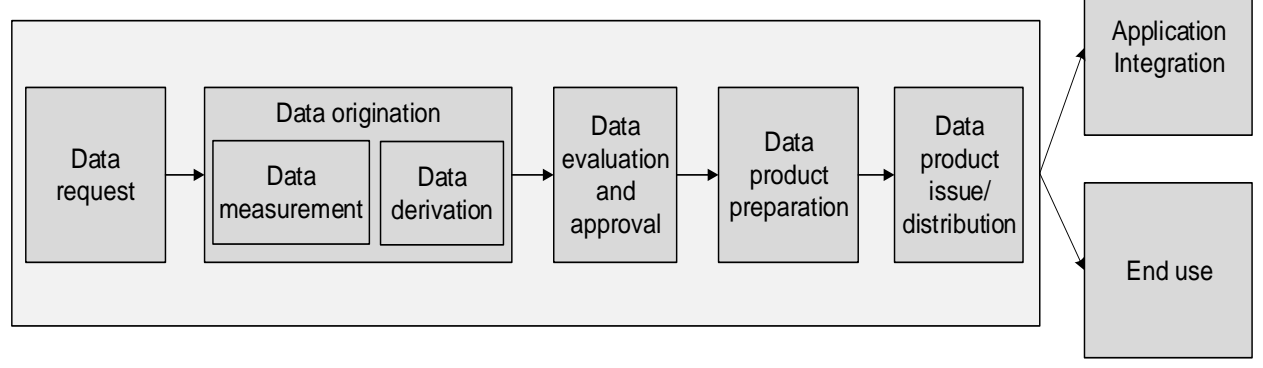

Fig. 2 Aeronautical data chain (based on [11])

In figure 3 a proceeding diagram for the entire aeronautical data and information chain, developed on the basis of figure 2 as well as practical experience, was shown.

It was noted that the obtained results' evaluation is only carried out after the completion of stages 1 and 2, respectively - data request and origination. It means that the process of incompatibilities' appearance control in the remaining chain stages (e.g. data product preparation, information publication or distribution) is not carried out at all. It can be, therefore, concluded that the chain, presented in Eurocontrol specification, does not conform to the proactive safety management formula as well as the quality assurance principle of aeronautical data and information, and that the use of the presented scheme (figure 3 ) in practice de facto prevents current incompatibilities' identification. 
The concept of risk tolerability matrix determination for aeronautical data... Koncepcja wyznaczenia macierzy tolerancji ryzyka dla łańcucha danych...

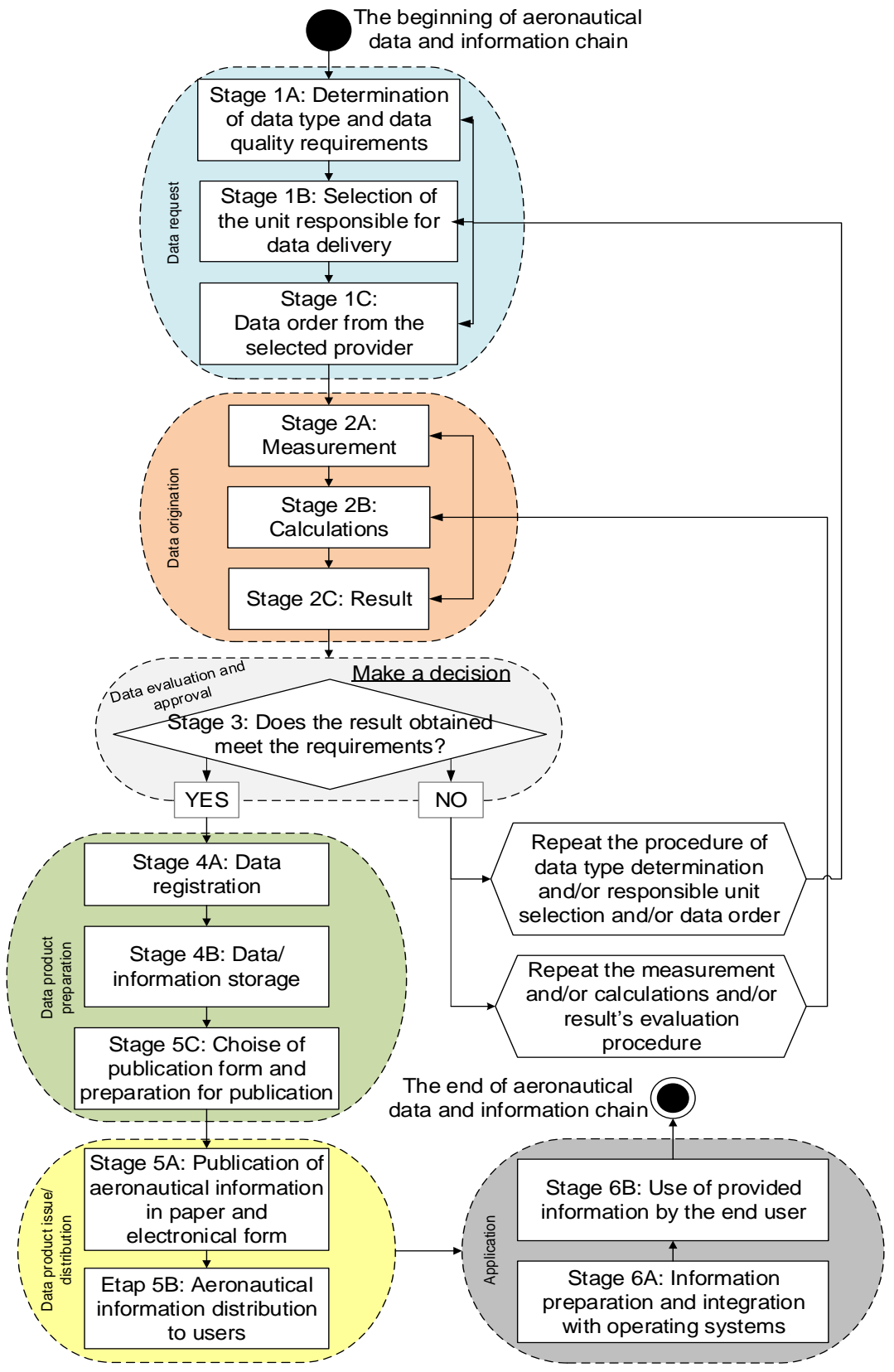

Fig. 3 Proceeeding diagram for the entire aeronautical data and information chain [own study] 
Consequently, this paper focuses on developing risk assessment and tolerability matrices of error and incompatibilities appearance in the entire aeronautical data and information chain.

\section{Risk assessment and tolerability matrices for aeronautical data and information chain}

One of the ways to quantify the outcome of a risk analysis is to classify the identified incompatibilities with respect to their criticality for the whole process [8]. This can be done by determining a risk tolerance matrix as the previously described function of probability of hazard's/incompatibilities' occurrence and their effects $(R=P \times S)$.

It is worth noting that in different applications different scales for variables $P$ and $S$ are used. In some cases, the assessment range is from 1 to 4 [9] or 5 (as in the risk tolerability matrix, presented in table 3 ), although typically $[5,7,9]$ each of these variables is assigned a value from 1 to 10 . According to the accepted nomenclature, the higher the value obtained, the greater the risk associated with the noncompliance. Based on the analysed international standards $[8,9]$ and literature $[5,7]$, the following 10 -value scales for parameters $P$ and $S$ were adopted (tables 4, 5). Moreover, an additional criteria table assessing the consequences of incompatibilities appearance directly rated to air transport has been developed (table 6).

Tab. 4 Criteria for probability/risk of incompatibilities' appearance assessment (based on [5, 7])

\begin{tabular}{|c|c|c|}
\hline $\begin{array}{l}\text { Incompatibility/error in } \\
\text { aeronautical data and } \\
\text { information appearance }\end{array}$ & $\begin{array}{c}\text { Variable } \\
P \\
\text { value }\end{array}$ & Criterion \\
\hline Improbable & 1 & $\begin{array}{l}\text { Error's appearance is improbable. Process } \\
\text { with very high quality. }\end{array}$ \\
\hline$\underline{\text { Rarely }}$ & $2-3$ & $\begin{array}{l}\text { An error is very rare and does not pose a } \\
\text { significant threat. }\end{array}$ \\
\hline Reasonably & $4-6$ & An error occurs occasionally. \\
\hline Often & $7-8$ & $\begin{array}{l}\text { An error occurs often and is a significant } \\
\text { threat. }\end{array}$ \\
\hline Very often & $9-10$ & $\begin{array}{l}\text { Error (almost) cannot be avoided. Process } \\
\text { with low quality. }\end{array}$ \\
\hline
\end{tabular}


The concept of risk tolerability matrix determination for aeronautical data... Koncepcja wyznaczenia macierzy tolerancji ryzyka dla łańcucha danych...

Tab. 5 Criteria for consequences/effects of incompatibilities' appearance assessment (based on [5, 7])

\begin{tabular}{|l|c|l|}
$\begin{array}{c}\text { Consequence/effects } \\
\text { of error's/ } \\
\text { incompatibilities } \\
\text { occurrence }\end{array}$ & $\begin{array}{c}\text { Variable } \\
\text { value }\end{array}$ & \multicolumn{1}{c|}{ Criterion } \\
\hline Meaningless & 1 & Remain unnoticed for the customer. \\
\hline Small & $2-3$ & $\begin{array}{l}\text { Defect's significance is small and leads only } \\
\text { to slight deterioration of product's properties. }\end{array}$ \\
\hline Average & $4-6$ & $\begin{array}{l}\text { Product's defect results in a noticeable user } \\
\text { discontent. The product does not meet the } \\
\text { needs or is a source of nuisance. }\end{array}$ \\
\hline Big & $7-8$ & $\begin{array}{l}\text { They are expressed in terms of the basic } \\
\text { system functions, but they do not violate the } \\
\text { law or concern a direct threat to safety. }\end{array}$ \\
\hline Very big & $9-10$ & $\begin{array}{l}\text { They are expressed in terms of safety or they } \\
\text { do violate the law. }\end{array}$ \\
\hline
\end{tabular}

The criteria for estimating the value of parameter $S$, presented above, refer to the overall quality of the product, which in the analysed case means to the degree to which the AIP product and any other aeronautical data and information meet the requirements at any stage of their creation, processing and use. These criteria, however, do not fully address the overarching attribute of aeronautical data and information quality, which is the assurance of air traffic safety and aircrafts' exploitation. It is therefore necessary to define the criteria for estimating the effects of aeronautical data and/or information incompatibilities appearance in the field of safety - variable $B$ in place of $S$. The above stated (according to Manual [10]) criteria to estimate the safety risk severity in 5-value scale (Table 2) and the definitions of the three aeronautical events categories, described in [12], are the formal basis for determining the criteria for estimating the effects in terms of safety. Adoption of the 10-degree scale of safety impact assessment allows definition of extended (in relation to $[10,15]$ ) criteria with a more detailed definition of the scale of human and material losses due to various circumstances of air events (place, phase of air operations, participation of aircraft, vehicles and other objects), arising from the appearance of aeronautical data and information errors/incompatibilities. Results, including effects, expressed in terms of damage scale and aircraft's exploitational condition, are presented in table 6. 
Tab. 6 Criteria for consequences/effects of incompatibilities' appearance assessment related directly to air transport (own study based on [5, 9, 13-15])

\begin{tabular}{|c|c|c|}
\hline $\begin{array}{c}\text { Severity of } \\
\text { consequences/effects }\end{array}$ & Assessment criterion & $\begin{array}{l}\text { Parameter } \\
B \\
\text { value }\end{array}$ \\
\hline None & $\begin{array}{l}\text { Air incident: aircraft's airworthiness } \\
\text { maintained - uninterrupted air operation. }\end{array}$ & 1 \\
\hline Very little & $\begin{array}{l}\text { Air incident: aircraft's airworthiness } \\
\text { maintained after confirmation - disturbed air } \\
\text { operation. }\end{array}$ & 2 \\
\hline Little & $\begin{array}{l}\text { Air incident: aircraft's airworthiness lost - } \\
\text { interrupted air operation, aircraft's damage } \\
\text { and repair. }\end{array}$ & 3 \\
\hline Very small & $\begin{array}{l}\text { Air incident: aircraft's airworthiness lost - } \\
\text { interrupted air operation, aircraft's repair. }\end{array}$ & 4 \\
\hline Small & $\begin{array}{l}\text { Serious air incident due to collision with a } \\
\text { bird or vehicle in the ground traffic area - } \\
\text { aircraft's damage and repair. }\end{array}$ & 5 \\
\hline Moderate & $\begin{array}{l}\text { Serious incident resulting from a collision } \\
\text { with an obstacle or an element of } \\
\text { aerodrome's infrastructure }- \text { aircraft's } \\
\text { damage and repair. }\end{array}$ & 6 \\
\hline Big & $\begin{array}{l}\text { Serious incident involving two (or more) } \\
\text { aircrafts. }\end{array}$ & 7 \\
\hline Bery big & $\begin{array}{l}\text { Air accident due to collision with a bird or } \\
\text { vehicle in the ground traffic area - aircraft's } \\
\text { damage and repair. }\end{array}$ & 8 \\
\hline Dangerous & $\begin{array}{l}\text { Air accident resulting from a collision with } \\
\text { an obstacle or an element of aerodrome's } \\
\text { infrastructure - aircraft's damage. }\end{array}$ & 9 \\
\hline Very dangerous & $\begin{array}{l}\text { Air accident involving two (or more) aircrafts } \\
\text { - aircraft's damage. }\end{array}$ & 10 \\
\hline
\end{tabular}

Referring the discussed issues to the analysed problem of risk assessment in aeronautical data and information chain, the Authors asked themselves how to set limit values in the risk tolerability matrix. Taking into account the three risk regions, adopted according to Manual [10]: acceptable, tolerable and unacceptable (described and illustrated in figure 1 and in table 3), it is necessary to set two limit values - the first separating the acceptable and the tolerable region and the second one defining limit values between the tolerable and the unacceptable region. To make it happen, the risk analysis for the analysed problem should begin with determination of the risk assessment matrix. 
The concept of risk tolerability matrix determination for aeronautical data... Koncepcja wyznaczenia macierzy tolerancji ryzyka dla łańcucha danych...

According to the accepted formula that each of the criteria used is assigned a value from 1 to 10, the developed tolerance matrix will have a dimension 10x10 (Table 7) and the values inside the table are obtained as multiplication result of the adequate numbers.

Tab. 7 The original version of the risk assessment matrix for aeronautical data and information chain [own study]

\begin{tabular}{|c|c|c|c|c|c|c|c|c|c|c|c|}
\hline & \multicolumn{10}{|c|}{ Effect } \\
\hline & & 10 & 9 & 8 & 7 & 6 & 5 & 4 & 3 & 2 & 1 \\
\hline \multirow{10}{*}{ 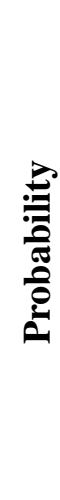 } & 10 & 100 & 90 & 80 & 70 & 60 & 50 & 40 & 30 & 20 & 10 \\
\hline & 9 & 90 & 81 & 72 & 63 & 54 & 45 & 36 & 27 & 18 & 9 \\
\hline & 8 & 80 & 72 & 64 & 56 & 48 & 40 & 32 & 24 & 16 & 8 \\
\hline & 7 & 70 & 63 & 56 & 49 & 42 & 35 & 28 & 21 & 14 & 7 \\
\hline & 6 & 60 & 54 & 48 & 42 & 36 & 30 & 24 & 18 & 12 & 6 \\
\hline & 5 & 50 & 45 & 40 & 35 & 30 & 25 & 20 & 15 & 10 & 5 \\
\hline & 4 & 40 & 36 & 32 & 28 & 24 & 20 & 16 & 12 & 8 & 4 \\
\hline & 3 & 30 & 27 & 24 & 21 & 18 & 15 & 12 & 9 & 6 & 3 \\
\hline & 2 & 20 & 18 & 16 & 14 & 12 & 10 & 8 & 6 & 4 & 2 \\
\hline & 1 & 10 & 9 & 8 & 7 & 6 & 5 & 4 & 3 & 2 & 1 \\
\hline
\end{tabular}

The risk assessment matrix, presented in table 7, is a result of the superposition of the risk tolerability matrix from [10] and presented in table 3 , on the probability and effect multiplication matrix. The results obtained can be written into the risk tolerability matrix (table 8).

Tab. 8 The original version of the risk tolerability matrix for aeronautical data and information chain [own study]

\begin{tabular}{|c|l|l|}
\hline Accepted evaluation criterion & $\begin{array}{l}\text { Risk assessment } \\
\text { index }\end{array}$ & $\begin{array}{l}\text { Criterion } \\
\text { description }\end{array}$ \\
\hline \multirow{2}{*}{$\begin{array}{c}\text { Intolerable region } \\
\text { Tolerable region }\end{array}$} & $\mathbf{4 5 - 1 0 0}$ & $\begin{array}{l}\text { The risk is } \\
\text { unacceptable at any } \\
\text { level. }\end{array}$ \\
\cline { 1 - 3 } & $7-48$ & $\begin{array}{l}\text { The risk is tolerable, } \\
\text { further analysis } \\
\text { required. }\end{array}$ \\
\hline $\begin{array}{c}\text { Acceptable } \\
\text { region }\end{array}$ & $\mathbb{1 - 2 0}$ & $\begin{array}{l}\text { The risk is acceptable } \\
\text { as it stands. }\end{array}$ \\
\hline
\end{tabular}


In the analysed issue, which is risk analysis of error/incompatibility occurrence in aeronautical data and information chain with respect to their impact on safety, risk assessment matrix (table 9) was developed, based on the exemplary analogous matrix published by ICAO in the SMM Manual [10], which was proportionally expanded from $5 \times 5$ to $10 \times 10$.

Tab. 9 Developed risk assessment matrix for aeronautical data and information chain [own study]

\begin{tabular}{|c|c|c|c|c|c|c|c|c|c|c|c|}
\hline & \multicolumn{10}{|c|}{ Effect } \\
\hline & & 10 & 9 & 8 & 7 & 6 & 5 & 4 & 3 & 2 & 1 \\
\hline \multirow{10}{*}{ 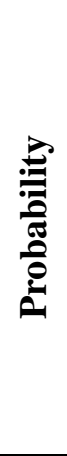 } & 10 & 100 & 90 & 80 & 70 & 60 & 50 & 40 & 30 & 20 & 10 \\
\hline & 9 & 90 & 81 & 72 & 63 & 54 & 45 & 36 & 27 & 18 & 9 \\
\hline & 8 & 80 & 72 & 64 & 56 & 48 & 40 & 32 & 24 & 16 & 8 \\
\hline & 7 & 70 & 63 & 56 & 49 & 42 & 35 & 28 & 21 & 14 & 7 \\
\hline & 6 & 60 & 54 & 48 & 42 & 36 & 30 & 24 & 18 & 12 & 6 \\
\hline & 5 & 50 & 45 & 40 & 35 & 30 & 25 & 20 & 15 & 10 & 5 \\
\hline & 4 & 40 & 36 & 32 & 28 & 24 & 20 & 16 & 12 & 8 & 4 \\
\hline & 3 & 30 & 27 & 24 & 21 & 18 & 15 & 12 & 9 & 6 & 3 \\
\hline & 2 & 20 & 18 & 16 & 14 & 12 & 10 & 8 & 6 & 4 & 2 \\
\hline & 1 & 10 & 9 & 8 & 7 & 6 & 5 & 4 & 3 & 2 & 1 \\
\hline
\end{tabular}

Based on the developed risk assessment matrix (Table 9), limit values were defined, pointing out the risk regions A, T and NA (Table 10).

Tab. 10 Modified risk tolerability matrix for aeronautical data and information chain [own study]

\begin{tabular}{|c|c|l|}
\hline Accepted evaluation criterion & $\begin{array}{c}\text { Risk } \\
\text { assessment } \\
\text { index }\end{array}$ & Criterion description \\
\hline \multirow{2}{*}{$\begin{array}{c}\text { Intolerable region } \\
\text { Tolerable region }\end{array}$} & $\mathbf{4 5 - 1 0 0}$ & $\begin{array}{l}\text { The risk is unacceptable at } \\
\text { any level, possible } \\
\text { consequence: air accident. }\end{array}$ \\
\cline { 2 - 3 } & $\mathbb{1 8 - 4 2}$ & $\begin{array}{l}\text { The risk is tolerable, } \\
\text { further analysis required. } \\
\text { Possible consequence: air } \\
\text { incident }\end{array}$ \\
\cline { 3 - 4 } & $1-16$ & $\begin{array}{l}\text { The risk is acceptable as } \\
\text { it stands, possible } \\
\text { consequence: incident }\end{array}$ \\
\hline
\end{tabular}


The concept of risk tolerability matrix determination for aeronautical data... Koncepcja wyznaczenia macierzy tolerancji ryzyka dla tańcucha danych...

In the risk tolerability matrix, presented in table 10 , the question of values discontinuity requires clarification. For example, the area of acceptable risk values is bounded by a value of 16 , and the minimum value for the tolerable risk area is 18. It could be said that the value 17 (as well as the values 43 and 44 for the second limit line) were lost. But this statement would not be true. Since the values of the risk assessment index are determined as the multiplication of values $P$ and $B$ (out of 1 to 10 range), there is no mathematical possibility to obtain the multiplication result equal to 17 (this is the prime number), or equal to 43 or 44 . So this is not an error in the developed risk tolerability matrix, but a certain discontinuity due to the fact that the non-existing risk assessment index values are not mathematically achievable with the assumed conditions.

\section{Summary, conclusions}

Due to the proactive safety management formula, described in $[6,9]$ and the identified need of incompatibilities' management, in this paper the concept of risk tolerability matrix determination for aeronautical data and information chain was presented. Limit values, separating the three risk regions according to [10]: T, A, and NA, were set.

The presented solution may provide the basis for a full risk analysis of the discussed problem with the use of FMEA/FMECA method with a quantitative summary of results, according to the Risk Priority Number $(R P N)$. This will require consideration and introduction of the incompatibilities detection parameter $-W$ in the analysed chain, as the RPN number is determined as the multiplication of the three evaluating criteria: risk/probability of failure occurrence (variable $P$ ), level of incompatibilities' detection (variable $W$ ) and consequence/effects of error's appearance (variable $S$ or the defined variable $B$ ). However, the described parameters $P$ and $S / B$ (from 1 to 10 ) are consistent with those used in FMEA method. Moreover, the limit values for risk regions T, A and NA could also be the limit values for the $R P N$ numbers.

This issue will be the subject of Authors further work.

\section{Literature}

[1] Dudek E., Kozłowski M.: Koncepcja procesu oceny jakości danych lotniczych, Prace Naukowe Politechniki Warszawskiej - Transport, z. 113, str. 131-140, Warszawa 2016, nr ISSN: 1230-9265.

[2] Dudek E., Kozłowski M.: Koncepcja zarządzania jakością danych lotniczych, Prace Naukowe Politechniki Warszawskiej - Transport, z. 113, str. 141-150, Warszawa 2016, nr ISSN: 1230-9265.

[3] Dudek E., Kozłowski M.: Koncepcja zastosowania metodyki DMAIC do zapewnienia jakości danych lotniczych, [w] Kwasiborska A. (red.): Transport lotniczy i jego otoczenie, Wydział Transportu Politechniki Warszawskiej, str. 67-78, Warszawa 2016, nr ISBN: 978-83-7814-548-6. 
[4] Dudek E., Kozłowski M.: The concept of a method ensuring aeronautical data quality, Journal of KONBiN No 1(37)2016, str. 319-340, Warszawa 2016, nr ISSN: 1895-8281.

[5] Hamrol A., Mantura W., Zarządzanie jakością: teoria i praktyka, Wydawnictwo Naukowe PWN, Warszawa, 2013.

[6] Krajowy Program Bezpieczeństwa w Lotnictwie Cywilnym, Ministerstwo Infrastruktury i Budownictwa, Urząd Lotnictwa Cywilnego, Warszawa, sierpień 2016.

[7] Myszewski J., Po prostu jakość: podręcznik zarządzania jakością, Wydawnictwa Akademickie i Profesjonalne, Warszawa 2009.

[8] Standard ISO 31010:2010, Risk management - Risk assessment techniques, 2010.

[9] Standard IEC 60812:2006, Analysis techniques for system reliability, Part 2 Procedure for failure mode and effects analysis (FMEA), 2006.

[10] Safety Management Manual - SMM - ICAO Doc. 9859.

[11] Eurocontrol Specification for Data Assurance Levels, Reference nr: EUROCONTROL-SPEC-148, 2012.

[12] Ustawa z dnia 3 lipca 2002 r. Prawo lotnicze, Dz.U. z 2017 r., poz. 959 i 1089.

[13] Annex 4 to the Convention on International Civil Aviation, Aeronautical Charts, 2009.

[14] Annex 8 to the Convention on International Civil Aviation, Airworthiness of Aircraft, 2010.

[15] Annex 13 to the Convention on International Civil Aviation, Aircraft Accident and Incident Investigation, 2010.

[16] Annex 19 to the Convention on International Civil Aviation, Safety Management, 2013.

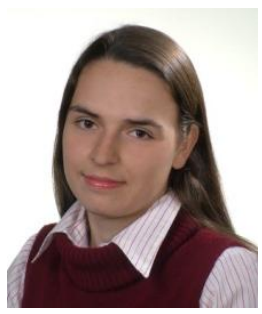

M.Sc. Eng. Ewa Dudek works as an assistant in the Telecommunication Department at Warsaw University of Technology, Faculty of Transport. Scientific interests cover transport telematics, system integration, issues related to air traffic control as well as automation of continuous processes (Share 50\%).

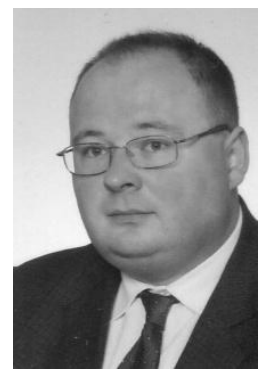

DPh. Eng. Michat Kozlowski - Assistant Professor in the Department of Air Transport Engineering at Warsaw University of Technology, Faculty of Transport. Extensive experience in airport managing, gained from over twenty years of work in the operating area of Warsaw Chopin Airport. Author of numerous studies, publications and implementations in the field of safety, quality, reliability and capacity (Share 50\%). 
The concept of risk tolerability matrix determination for aeronautical data... Koncepcja wyznaczenia macierzy tolerancji ryzyka dla tańcucha danych...

\section{KONCEPCJA WYZNACZENIA MACIERZY TOLERANCJI RYZYKA DLA LAŃCUCHA DANYCH I INFORMACJI LOTNICZYCH}

\section{Wstęp}

Zgodnie $\mathrm{z}$ obowiązującymi $\mathrm{w}$ lotnictwie cywilnym standardami zarządzania bezpieczeństwem, w szczególności dotyczącymi systemów zarządzania bezpieczeństwem (Safety Management System - SMS) [10], zarządzanie to powinno cechować się systematycznością, jawnością oraz proaktywnością. $\mathrm{Na}$ obecnym etapie rozważań szczególną uwagę zwrócono na tę ostatnią cechę. Proaktywne zarządzanie bezpieczeństwem oznacza, iż główny nacisk powinien być kładziony na zapobieganie zdarzeniom poprzez identyfikację zagrożeń oraz nadzorowanie i wprowadzanie środków łagodzenia ryzyka, zanim wystąpi zdarzenie skutkujące materializacją zagrożenia. Wychwytywanie, wczesne wykrywanie błędów oraz niezgodności i zapobieganie ich skutkom zanim do nich dojdzie stanowi więc podstawę wymaganego przepisami podejścia do zapewnienia bezpieczeństwa. Jak zapisano $\mathrm{w}$ [6] "identyfikowanie przyszłych zagrożeń ma być formą zarządzania znacznie bardziej efektywną od podejmowania działań o charakterze korygującym i naprawczym (tzw. podejście reaktywne), kiedy już doszło do niepożądanych zdarzeń, a tym samym nie można cofnąć ich skutków".

Niniejsza publikacja stanowi kontynuację prac Autorów nad zagadnieniem zapewnienia jakości danych $\mathrm{i}$ informacji lotniczych $\mathrm{w}$ całym procesie (rozpatrywanym jako łańcuch dostaw) ich tworzenia, gromadzenia, przetwarzania i publikacji. We wcześniejszych pracach $[1,2,4]$ omówiono wymagania, procedury i przepisy wykonawcze obowiązujące $\mathrm{w}$ lotnictwie cywilnym, a mające na celu zapewnienie odpowiedniego poziomu bezpieczeństwa operacji lotniczych. Jako iż efektywność i skuteczność funkcjonowania transportu lotniczego jest w ogromnym stopniu uzależniona od dostarczania informacji odpowiedniej jakości zaproponowano (np. w [2, 3]) kompleksowe i systemowe podejście do zapewnienia jakości na wszystkich etapach łańcucha danych i informacji lotniczych. W niniejszej publikacji skupiono się na proaktywnym podejściu do zarządzania bezpieczeństwem ruchu lotniczego, a biorąc pod uwagę wymagania, opublikowanego w sierpniu 2016 roku Krajowego Programu Bezpieczeństwa w Lotnictwie Cywilnym [6] i opisaną w nim konieczność implementacji Systemu Monitorowania Zgodności (ang. Compliance Monitoring System - CMS), opartego na zasadach, związanych z Zarządzaniem Jakością (Quality Management System QMS) oraz jego integrację z systemem SMS, w odniesieniu do analizowanego łańcucha danych i informacji lotniczych stwierdzono, iż każda wykryta niezgodność musi być zarządzana. Proces ten, zdaniem Autorów, należy rozpocząć od wyznaczenia macierzy oceny/tolerancji ryzyka wystąpienia błędu/niezgodności w łańcuchu danych i informacji lotniczych, co w przyszłości umożliwi ocenę ryzyka i (tak istotne $\mathrm{w}$ procesie zarządzania bezpieczeństwem) proaktywne wychwytywanie błędów oraz zarządzanie wykrytymi niezgodnościami. 


\section{Ocena ryzyka}

Zgodnie z Krajowym Programem Bezpieczeństwa w Lotnictwie Cywilnym (KPBwLC) [6] zarządzanie ryzykiem obejmuje dwa obszary:

- procesy identyfikowania zagrożeń,

- procesy oceny i ograniczania ryzyka.

Aby należycie zrozumieć ogólne pojęcie samego ryzyka oraz bardziej konkretne ryzyka bezpieczeństwa posłużono się następującymi definicjami, zawartymi w podstawowych dokumentach ICAO, dotyczących bezpieczeństwa:

Ryzyko (ang. Risk) [10] - konsekwencja zagrożenia wyrażona miarą prawdopodobieństwa i/lub częstości jego występowania.

Ryzyko bezpieczeństwa (ang. Safety risk) wg [10] zostało zdefiniowane jako ocena, wyrażona $\mathrm{W}$ przewidywanym prawdopodobieństwie i dotkliwości konsekwencji wystąpienia zagrożeń, biorąca jako punkt odniesienia najgorszą, dającą się przewidzieć sytuację.

Zarządzanie ryzykiem bezpieczeństwa [10] natomiast jest ogólnym terminem zawierającym ocenę i łagodzenie ryzyka bezpieczeństwa konsekwencji zagrożeń dla organizacji, do poziomu najniższego z możliwych (ang. as low as reasonably practicable - ALARP).

$\mathrm{W}$ procesie ewaluacji ryzyka wyznaczono 3 poziomy ryzyka: akceptowalne $-\mathrm{A}$, tolerowalne - $\mathrm{T}$ oraz nietolerowalne (nieakceptowalne) - NA. Graficzną prezentację procesu zarządzania ryzykiem stanowi odwrócony trójkąt (rysunek 1).

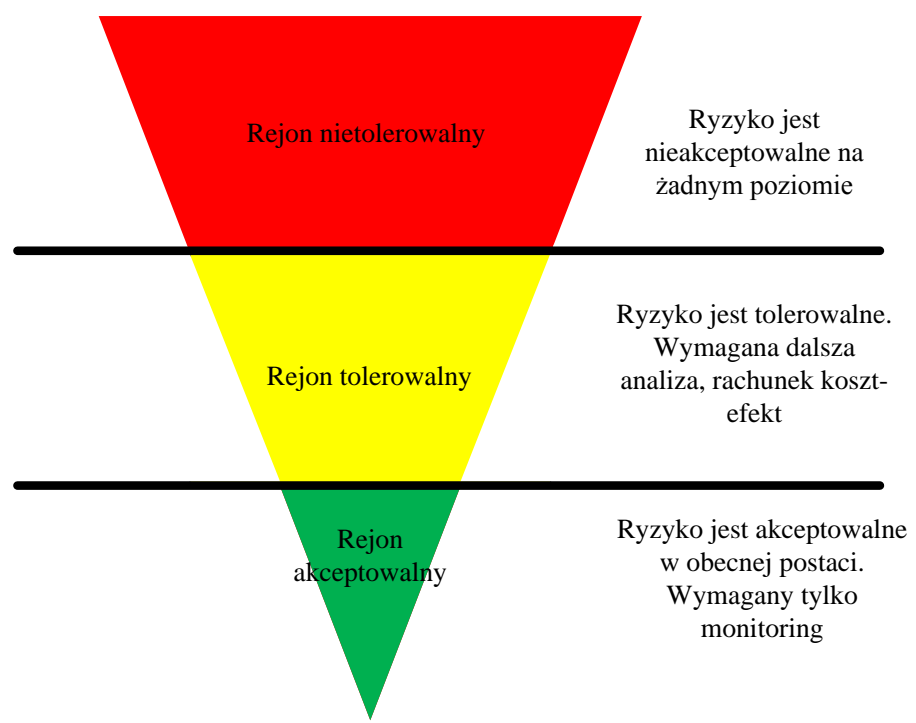

Rys. 1 Poziomy ryzyka w procesie zarządzania ryzykiem bezpieczeństwa (opracowanie na podstawie [10]) 
The concept of risk tolerability matrix determination for aeronautical data...

Koncepcja wyznaczenia macierzy tolerancji ryzyka dla łańcucha danych...

Analiza Podręcznika Zarządzania Bezpieczeństwem, ICAO Doc. 9859 [10] oraz Załącznika 19 do Konwencji o międzynarodowym lotnictwie cywilnym Zarządzanie Bezpieczeństwem [16] prowadzi do wniosku, iż ryzyko bezpieczeństwa w systemie zarządzania ruchem lotniczym (ATM) jest wyrażane jako kombinacja oszacowania wartości dwóch czynników: prawdopodobieństwa i skutku (dotkliwości) danego zdarzenia.

$$
R=P x S,
$$

gdzie:

$R$ - poziom ryzyka bezpieczeństwa,

$P$ - prawdopodobieństwo wystąpienia zagrożenia,

$S$ - skutki wystąpienia zagrożenia.

Takie podejście umożliwia przeprowadzenie oceny ryzyka bezpieczeństwa względem konsekwencji zagrożenia, jeżeli jego potencjał niszczący ujawni się podczas wykonywanej operacji. Podręcznik [10] proponuje następujące kryteria szacowania prawdopodobieństwa wystąpienia ryzyka (Tabela 1) i dotkliwości zdarzenia (Tabela 2) oraz kryteria ewaluacji (tolerancji) ryzyka (Tabela 3):

Tab. 1 Prawdopodobieństwo ryzyka bezpieczeństwa (opracowanie na podstawie [10])

\begin{tabular}{|l|c|l|l|}
\hline \multicolumn{2}{|c|}{ STOPIDN } & \multicolumn{2}{c|}{ ZNACZENIE } \\
\hline PRAWDOPODOBIte & 5 & $\begin{array}{l}\text { Prawdopodobnie wystąpi/występowało } \\
\text { często }\end{array}$ \\
\hline Sporadycrane & 4 & $\begin{array}{l}\text { Prawdopodobnie wystąpi/występowało } \\
\text { sporadycznie }\end{array}$ \\
\hline Niewielkie & 3 & $\begin{array}{l}\text { Prawdopodobnie nie wystąpi, ale jest to } \\
\text { możliwe lub występowało rzadko }\end{array}$ \\
\hline Nieprawdopodobne & 2 & $\begin{array}{l}\text { Bardzo mało prawdopodobne, że wystąpi; } \\
\text { nieznany jest przypadek by wystąpiło }\end{array}$ \\
\hline $\begin{array}{l}\text { Skrajnie } \\
\text { nieprawdopodobne }\end{array}$ & 1 & $\begin{array}{l}\text { Prawie niewyobrażalne, że kiedykolwiek } \\
\text { może wystąpić }\end{array}$ \\
\hline
\end{tabular}

Tab. 2 Dotkliwość ryzyka bezpieczeństwa (opracowanie na podstawie [10])

\begin{tabular}{|c|c|c|}
\hline $\begin{array}{l}\text { DOTKLIWOŚĆ } \\
\text { ZDARZENIA }\end{array}$ & SKALA & ZNACZENIE \\
\hline Katastrofalna & 5 & $\begin{array}{l}\text { Ogromne zagrożenie bezpieczeństwa - wiele ofiar, } \\
\text { zniszczenie sprzętu }\end{array}$ \\
\hline Niebezpieczna & 4 & $\begin{array}{l}\text { Poważne zagrożenie bezpieczeństwa - poważne } \\
\text { obrażenia ciała, duże straty w sprzęcie }\end{array}$ \\
\hline Poważna & 3 & $\begin{array}{l}\text { Znaczne zagrożenie bezpieczeństwa - poważny } \\
\text { incydent, obrażenia ciała }\end{array}$ \\
\hline Niewielka & 2 & $\begin{array}{l}\text { Nieznaczny wpływ na bezpieczeństwo - incydent, } \\
\text { uciążliwość, ograniczenia operacyjne, użycie } \\
\text { procedur awaryjnych }\end{array}$ \\
\hline Nieistotna & 1 & $\begin{array}{l}\text { Brak wpływu na bezpieczeństwo }- \text { małe } \\
\text { konsekwencje }\end{array}$ \\
\hline
\end{tabular}


Ewa Dudek, Michat Kozłowski

Tab. 3 Macierz tolerancji ryzyka (opracowanie na podstawie [10])

\begin{tabular}{|lc|c|c|c|c|c|}
\hline \multirow{2}{*}{$\begin{array}{l}\text { Prawdopodobieństwo } \\
\text { ryzyka }\end{array}$} & & \multicolumn{2}{|c|}{ Dotkliwość ryzyka } \\
\cline { 3 - 7 } & & $\begin{array}{c}\text { Katastrof. } \\
5\end{array}$ & $\begin{array}{c}\text { Niebezp. } \\
4\end{array}$ & $\begin{array}{c}\text { Poważna } \\
3\end{array}$ & $\begin{array}{c}\text { Niewiel. } \\
2\end{array}$ & $\begin{array}{c}\text { Nieistot. } \\
1\end{array}$ \\
\hline Częste & 5 & NA & NA & NA & T & T \\
\hline Sporadyczne & 4 & NA & NA & T & T & T \\
\hline Niewielkie & 3 & NA & T & T & T & A \\
\hline Nieprawdopodobne & 2 & T & T & T & A & A \\
\hline $\begin{array}{l}\text { Skrajnie } \\
\text { nieprawdopodobne }\end{array}$ & 1 & A & A & A & A & A \\
\hline
\end{tabular}

\section{Lańcuch danych i informacji lotniczych}

Samą ideę łańcucha danych/informacji lotniczych autorzy opisali szerzej w swoich poprzednich pracach [np. w 3,4], zaznaczając iż łańcuch ten reprezentuje kolejne etapy produkcji oraz przetwarzania danych i informacji lotniczych, poczynając od ich zamówienia i tworzenia, aż do wykorzystania końcowego (rysunek 2).
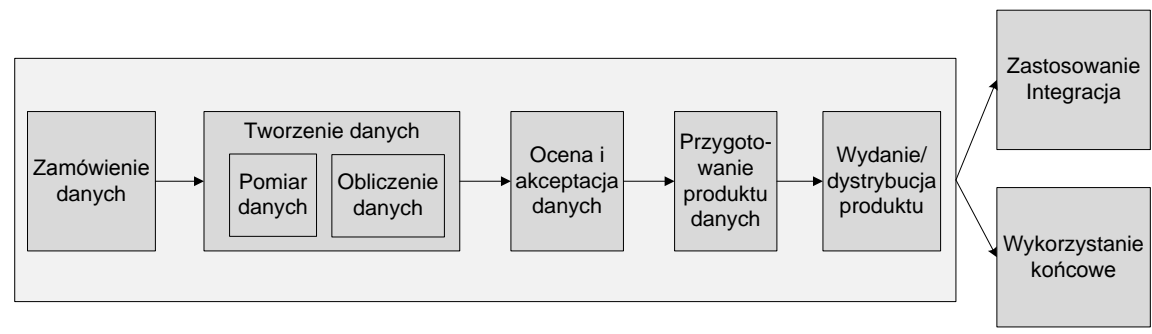

Rys. 2 Łańcuch danych lotniczych (na podstawie [11])

$\mathrm{Na}$ bazie rysunku 2 oraz doświadczeń praktycznych, na potrzeby dalszych rozważań opracowano schemat postępowania w całym omawianym łańcuchu danych i informacji lotniczych, przedstawiony na rysunku 3.

Co więcej, zauważono iż ocena uzyskanych wyników jest prowadzona dopiero po zakończeniu etapów 1 oraz 2, czyli odpowiednio zamówienia i tworzenia danych lotniczych. Oznacza to, iż proces kontroli wystąpienia niezgodności w pozostałych etapach łańcucha (np. przygotowania produktu danych, publikacji czy dystrybucji informacji) nie jest prowadzony wcale. Nasuwa się więc wniosek, iż przedstawiony $\mathrm{w}$ specyfikacji Eurocontrol łańcuch nie pozostaje $\mathrm{w}$ zgodzie $\mathrm{z}$ formułą proaktywnego zarządzania bezpieczeństwem i zapewnienia jakości danych i informacji lotniczych, a stosowanie przedstawionego schematu (rysunek 3) w praktyce de facto uniemożliwia bieżącą identyfikację niezgodności.

W związku z tym, w niniejszej pracy skupiono się na opracowaniu macierzy tolerancji i oceny ryzyka wystąpienia błędu lub niezgodności w całym łańcuchu danych i informacji lotniczych. 
The concept of risk tolerability matrix determination for aeronautical data... Koncepcja wyznaczenia macierzy tolerancji ryzyka dla łańcucha danych...

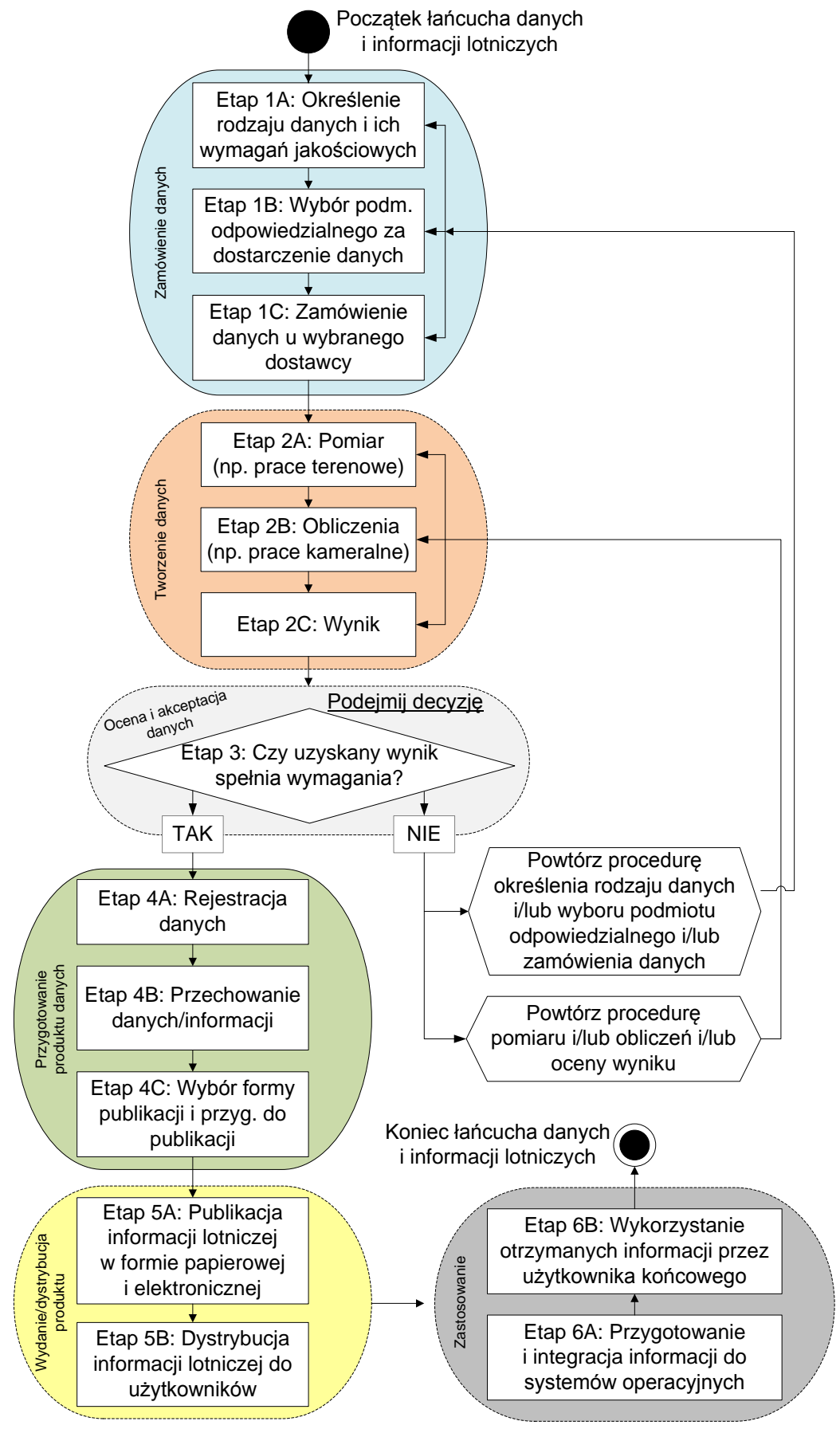

Rys.3 Schemat postepowania w calym łańcuchu danych i informacji lotniczych [opracowanie wlasne] 


\section{Macierze oceny i tolerancji ryzyka dla lańcucha danych i informacji lotniczych}

Jedną z metod ilościowego określenia wyniku analizy ryzyka jest klasyfikacja zidentyfikowanych niezgodności w odniesieniu do ich krytyczności dla całego procesu [8]. Można tego dokonać określając macierz tolerancji ryzyka, jako opisaną wcześniej funkcję prawdopodobieństwa wystąpienia zagrożenia/niezgodności i jego skutków $(R=P \times S)$.

Warto zaznaczyć, iż w różnych zastosowaniach przyjmuje się różne skale wartości parametrów $P$ i $S$. W niektórych przypadkach jest to ocena z zakresu od 1 do 4 [9] lub do 5 (jak w zaprezentowanej w Tabeli 3 macierzy tolerancji ryzyka), choć zazwyczaj $[5,7,9]$ każdemu z wymienionych kryteriów przypisuje się wartości od 1 do 10. Zgodnie z przyjmowaną nomenklaturą, im wyższa uzyskana wartość, tym ryzyko związane $\mathrm{z}$ daną niezgodnością jest większe. $\mathrm{Na}$ podstawie przeanalizowanych standardów międzynarodowych [8,9] oraz literatury [np. 5, 7], przyjęto następujące dziesięciostopniowe skale parametrów $P$ oraz $S$ (tabele 4,5). Ponadto, dla skutków opracowano dodatkową tabelę $\mathrm{z}$ kryteriami oceny konsekwencji wystąpienia niezgodności w bezpośrednim odniesieniu do transportu lotniczego (tabela 6).

Tab. 4 Kryterium oceny prawdopodobieństwa/ryzyka wystapienia niezgodności (opracowanie na podstawie [5, 7])

\begin{tabular}{|l|c|c|}
$\begin{array}{c}\text { Wystąpienie } \\
\text { niezgodności/błędu } \\
\text { danych } \\
\text { i informacji lotniczych }\end{array}$ & $\begin{array}{c}\text { Wartość } \\
\text { parametru } \\
\boldsymbol{P}\end{array}$ & \multicolumn{1}{c|}{ Kryterium } \\
\hline Mało prawdopodobne & 1 & $\begin{array}{l}\text { Wystąpienie wady jest } \\
\text { nieprawdopodobne. Proces o bardzo } \\
\text { wysokiej zdolności jakościowej. }\end{array}$ \\
\hline$\underline{\text { Rzadko }}$ & $2-3$ & $\begin{array}{l}\text { Wada występuje bardzo rzadko i nie } \\
\text { stanowi istotnego zagrożenia. }\end{array}$ \\
\hline$\underline{\text { Umiarkowanie }}$ & $4-6$ & $\begin{array}{l}\text { Wada występuje sporadycznie, co jakiś } \\
\text { czas. }\end{array}$ \\
\hline$\underline{\text { Czesto }}$ & $7-8$ & $\begin{array}{l}\text { Wada występuje często i stanowi istotne } \\
\text { zagrożenie }\end{array}$ \\
\hline Bardzo czessto & $9-10$ & $\begin{array}{l}\text { Wady (prawie) nie da się uniknąć. Proces } \\
\text { o niskiej zdolności jakościowej. }\end{array}$ \\
\hline
\end{tabular}


The concept of risk tolerability matrix determination for aeronautical data... Koncepcja wyznaczenia macierzy tolerancji ryzyka dla tańcucha danych...

Tab. 5 Kryterium oceny konsekwencji/skutków wystapienia niezgodności (opracowanie na podstawie [5, 7])

\begin{tabular}{|c|c|c|}
\hline $\begin{array}{l}\text { Konsekwencje/skutki } \\
\text { wystąpienia } \\
\text { niezgodności/błędu }\end{array}$ & $\begin{array}{l}\text { Wartość } \\
\text { parametru } \\
\quad S\end{array}$ & Kryterium \\
\hline Nie ma znaczenia & 1 & Pozostaną niezauważalne dla klienta \\
\hline$\underline{\text { Małe }}$ & $2-3$ & $\begin{array}{l}\text { Znaczenie wady jest małe i prowadzi } \\
\text { jedynie do niewielkiego pogorszenia } \\
\text { właściwości wyrobu. }\end{array}$ \\
\hline Przecietne & 4-6 & $\begin{array}{l}\text { Wada wyrobu powoduje wyraźne } \\
\text { niezadowolenie użytkownika. Wyrób nie } \\
\text { zaspokaja potrzeb lub jest źródłem } \\
\text { uciążliwości. }\end{array}$ \\
\hline Duże & $7-8$ & $\begin{array}{l}\text { Wyrażają się w kategoriach podstawowych } \\
\text { funkcji systemu jednak nie naruszają } \\
\text { przepisów prawa ani nie dotyczą } \\
\text { bezpośredniego zagrożenia bezpieczeństwa }\end{array}$ \\
\hline Bardzo duże & $9-10$ & $\begin{array}{l}\text { Wyrażają się w kategoriach bezpieczeństwa } \\
\text { lub naruszaja przepisy prawa. }\end{array}$ \\
\hline
\end{tabular}

Przedstawione powyżej kryteria szacowania wartości parametru $S$ odnoszą się do ogólnie rozumianej jakości produktu, czyli w przedmiocie rozważań do stopnia spełnienia wymagań przez Produkt AIP oraz wszelkie inne dane i informacje lotnicze, na każdym etapie ich tworzenia, przetwarzania i wykorzystania. Tak określone kryteria nie odnoszą się w pełni adekwatnie do nadrzędnego atrybutu jakości danych i informacji lotniczych, jakim jest zapewnienie bezpieczeństwa ruchu lotniczego i eksploatacji statków powietrznych. Zachodzi więc konieczność zdefiniowania kryteriów szacowania skutków wystąienia niezgodności danych i/lub informacji lotniczych, w dziedzinie bezpieczeństwa - parametr $B$ w miejsce $S$. Powyżej przedstawione (za Podręcznikiem [10]) kryteria szacowania dotkliwości ryzyka bezpieczeństwa w skali 5-stopniowej (Tabela 8) oraz opisane w [12] definicje trzech kategorii zdarzeń lotniczych stanowią formalną podstawę do określenia kryteriów szacowania skutków w odniesieniu do bezpieczeństwa. Przyjęcie 10-stopniowej skali szacowania skutków bezpieczeństwa umożliwia określenie rozszerzonych (w stosunku do [10, 15]) kryteriów, z bardziej szczegółowym określeniem skali wielkości strat ludzkich i materialnych ze względu na różne okoliczności (miejsce, faza operacji lotniczej, udział statków powietrznych, pojazdów i innych obiektów) zdarzeń lotniczych, zaistniałych na skutek wystąpienia błędów lub niezgodności danych i informacji lotniczych. Wyniki, z uwzględnieniem skutków, wyrażone w postaci skali zniszczeń i stanu eksploatacyjnego statku powietrznego, przedstawiono w Tabeli 6 . 
Tab. 6 Kryteria oceny konsekwencji/skutków wystapienia niezgodności w odniesieniu do transportu lotniczego (opracowanie wtasne na podstawie [5, 9, 13-15])

\begin{tabular}{|c|c|c|}
\hline $\begin{array}{c}\text { Dotkliwość } \\
\text { konsekwencji/skutków }\end{array}$ & Kryterium oceny & $\begin{array}{l}\text { Wartość } \\
\text { parametru } \\
\text { B }\end{array}$ \\
\hline Zerowe & $\begin{array}{l}\text { Incydent lotniczy: zachowana ciągła } \\
\text { zdatność do lotu statku powietrznego - } \\
\text { niezakłócona operacja lotnicza. }\end{array}$ & 1 \\
\hline Bardzo niewielkie & $\begin{array}{l}\text { Incydent lotniczy: zachowana po } \\
\text { potwierdzeniu zdatność do lotu statku } \\
\text { powietrznego }- \text { zakłócona operacja } \\
\text { lotnicza. }\end{array}$ & 2 \\
\hline Niewielkie & $\begin{array}{l}\text { Incydent lotniczy: utracona zdatność do } \\
\text { lotu statku powietrznego - przerwana } \\
\text { operacja lotnicza, uszkodzenie i reperacja } \\
\text { statku powietrznego. }\end{array}$ & 3 \\
\hline Bardzo małe & $\begin{array}{l}\text { Incydent lotniczy: utracona ciągła } \\
\text { zdatność do lotu statku powietrznego - } \\
\text { przerwana operacja lotnicza i reperacja. }\end{array}$ & 4 \\
\hline Małe & $\begin{array}{l}\text { Poważny incydent lotniczy na skutek } \\
\text { zderzenia z ptakami lub pojazdem na } \\
\text { polu ruchu naziemnego - uszkodzenie i } \\
\text { reperacja statku powietrznego. }\end{array}$ & 5 \\
\hline Umiarkowane & $\begin{array}{l}\text { Poważny incydent na skutek kolizji z } \\
\text { przeszkodą lotniczą lub elementem } \\
\text { infrastruktury lotniskowej - uszkodzenie } \\
\text { i reperacja statku powietrznego. }\end{array}$ & 6 \\
\hline Wysokie & $\begin{array}{l}\text { Poważny incydent z udziałem dwóch (lub } \\
\text { więcej) statków powietrznych. }\end{array}$ & 7 \\
\hline Bardzo wysokie & $\begin{array}{l}\text { Wypadek lotniczy na skutek zderzenia } \mathrm{z} \\
\text { ptakami lub pojazdem na polu ruchu } \\
\text { naziemnego-- uszkodzenie i reperacja } \\
\text { statku powietrznego. }\end{array}$ & 8 \\
\hline Niebezpieczne & $\begin{array}{l}\text { Wypadek lotniczy na skutek kolizji z } \\
\text { przeszkodą lotniczą lub elementem } \\
\text { infrastruktury lotniskowej - zniszczenie } \\
\text { statku powietrznego. }\end{array}$ & 9 \\
\hline Bardzo niebezpieczne & $\begin{array}{l}\text { Wypadek lotniczy z udziałem dwóch (lub } \\
\text { więcej) statków powietrznych- } \\
\text { zniszczenie statku powietrznego. }\end{array}$ & 10 \\
\hline
\end{tabular}

Odnosząc przedstawione rozważania do analizowanego zagadnienia oceny ryzyka w łańcuchu danych i informacji lotniczych Autorzy zadali sobie pytanie o sposób wyznaczenia wartości granicznych w macierzy tolerancji ryzyka. Biorąc pod uwagę przyjęte na podstawie Podręcznika [10] w analizie ryzyka 3 poziomy ryzyka: akceptowalne, tolerowalne oraz nieakceptowalne (opisane i zilustrowane na rysunku 1 oraz w tabeli 3) koniecznym wydaje się ustalenie dwóch wartości granicznych - pierwszej oddzielającej poziom akceptowalny od tolerowalnego oraz drugiej, wyznaczającej granice między rejonem tolerowalnym i nieakceptowalnym. 
The concept of risk tolerability matrix determination for aeronautical data...

Koncepcja wyznaczenia macierzy tolerancji ryzyka dla łańcucha danych...

Aby tego dokonać, analizę ryzyka dla omawianego zagadnienia rozpoczęto od określenia macierzy oceny ryzyka. Zgodnie z przyjętą formułą, iż każdemu $\mathrm{z}$ wymienionych kryteriów przypisuje się wartości od 1 do 10, opracowana macierz tolerancji będzie miała wymiar 10x10 (Tabela 7), a wartości wewnątrz tabeli są iloczynami odpowiednich liczb.

Tab. 7 Pierwotna wersja macierzy oceny ryzyka dla tańcucha danych i informacji lotniczych [opracowanie własne]

\begin{tabular}{|c|c|c|c|c|c|c|c|c|c|c|c|}
\hline & \multicolumn{10}{|c|}{ Skutek } \\
\hline & & 10 & 9 & 8 & 7 & 6 & 5 & 4 & 3 & 2 & 1 \\
\hline \multirow{10}{*}{ 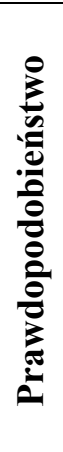 } & 10 & 100 & 90 & 80 & 70 & 60 & 50 & 40 & 30 & 20 & 10 \\
\hline & 9 & 90 & 81 & 72 & 63 & 54 & 45 & 36 & 27 & 18 & 9 \\
\hline & 8 & 80 & 72 & 64 & 56 & 48 & 40 & 32 & 24 & 16 & 8 \\
\hline & 7 & 70 & 63 & 56 & 49 & 42 & 35 & 28 & 21 & 14 & 7 \\
\hline & 6 & 60 & 54 & 48 & 42 & 36 & 30 & 24 & 18 & 12 & 6 \\
\hline & 5 & 50 & 45 & 40 & 35 & 30 & 25 & 20 & 15 & 10 & 5 \\
\hline & 4 & 40 & 36 & 32 & 28 & 24 & 20 & 16 & 12 & 8 & 4 \\
\hline & 3 & 30 & 27 & 24 & 21 & 18 & 15 & 12 & 9 & 6 & 3 \\
\hline & 2 & 20 & 18 & 16 & 14 & 12 & 10 & 8 & 6 & 4 & 2 \\
\hline & 1 & 10 & 9 & 8 & 7 & 6 & 5 & 4 & 3 & 2 & 1 \\
\hline
\end{tabular}

Przedstawiona w tabeli 7 macierz oceny ryzyka powstała w wyniku nałożenia na macierz iloczynów prawdopodobieństwa i skutków macierzy oceny ryzyka bezpieczeństwa $\mathrm{z}[10]$, przedstawionej $\mathrm{w}$ tabeli 3. Otrzymane wyniki można wpisać do macierzy tolerancji ryzyka (tabela 8).

Tab. 8 Pierwotna wersja macierzy oceny ryzyka dla łańcucha danych i informacji lotniczych [opracowanie własne]

\begin{tabular}{|c|c|c|}
\hline Przyjęte kryterium oceny & $\begin{array}{c}\text { Indeks oceny } \\
\text { ryzyka }\end{array}$ & Opis kryterium \\
\hline Rejon n & $45-100$ & $\begin{array}{l}\text { Ryzyko jest nieakceptowalne } \\
\text { na żadnym poziomie }\end{array}$ \\
\hline Rejon tolerowalny & $7-48$ & $\begin{array}{l}\text { Ryzyko jest tolerowalne, } \\
\text { wymagana dalsza analiza }\end{array}$ \\
\hline & $1-20$ & $\begin{array}{l}\text { Ryzyko jest akceptowalne } \\
\text { w obecnej postaci }\end{array}$ \\
\hline
\end{tabular}


W rozważanym zagadnieniu, tj. analizy ryzyka wystąpienia błędu lub niezgodności w łańcuchu danych i informacji lotniczych, w odniesieniu do wpływu na bezpieczeństwo, opracowano (Tabela 9) macierz tolerancji ryzyka, w oparciu o przykładową analogiczną macierz opublikowaną przez Radę ICAO w Podręczniku SMM [10], którą proporcjonalnie rozszerzono z wymiaru 5x5, do wymiaru 10x10.

Tab. 9 Opracowana macierz oceny ryzyka dla tańcucha danych i informacji lotniczych [opracowanie własne]

\begin{tabular}{|c|c|c|c|c|c|c|c|c|c|c|c|}
\hline & \multicolumn{10}{|c|}{ Skutek } \\
\hline & & 10 & 9 & 8 & 7 & 6 & 5 & 4 & 3 & 2 & 1 \\
\hline \multirow{10}{*}{ 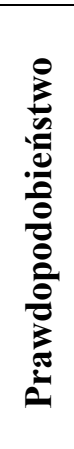 } & 10 & 100 & 90 & 80 & 70 & 60 & 50 & 40 & 30 & 20 & 10 \\
\hline & 9 & 90 & 81 & 72 & 63 & 54 & 45 & 36 & 27 & 18 & 9 \\
\hline & 8 & 80 & 72 & 64 & 56 & 48 & 40 & 32 & 24 & 16 & 8 \\
\hline & 7 & 70 & 63 & 56 & 49 & 42 & 35 & 28 & 21 & 14 & 7 \\
\hline & 6 & 60 & 54 & 48 & 42 & 36 & 30 & 24 & 18 & 12 & 6 \\
\hline & 5 & 50 & 45 & 40 & 35 & 30 & 25 & 20 & 15 & 10 & 5 \\
\hline & 4 & 40 & 36 & 32 & 28 & 24 & 20 & 16 & 12 & 8 & 4 \\
\hline & 3 & 30 & 27 & 24 & 21 & 18 & 15 & 12 & 9 & 6 & 3 \\
\hline & 2 & 20 & 18 & 16 & 14 & 12 & 10 & 8 & 6 & 4 & 2 \\
\hline & 1 & 10 & 9 & 8 & 7 & 6 & 5 & 4 & 3 & 2 & 1 \\
\hline
\end{tabular}

Na podstawie opracowanej macierzy oceny ryzyka (tabela 9), określono wartości graniczne, wyznaczające odpowiednio przedziały ryzyka: A, T i NA (Tabela 10).

Tabela 10. Zmodyfikowana macierz tolerancji ryzyka dla tańcucha danych i informacji lotniczych [opracowanie wtasne]

\begin{tabular}{|c|c|l|}
\hline Przyjęte kryterium oceny & $\begin{array}{c}\text { Indeks } \\
\text { oceny } \\
\text { ryzyka }\end{array}$ & \multicolumn{1}{|c|}{ Opis kryterium } \\
\hline \multirow{2}{*}{$\begin{array}{c}\text { Rejon nietolerowalny } \\
\text { Rejon tolerowalny }\end{array}$} & $45-100$ & $\begin{array}{l}\text { Ryzyko jest nieakceptowalne } \\
\text { na żadnym poziomie; } \\
\text { możliwy skutek: wypadek } \\
\text { lotniczy }\end{array}$ \\
\cline { 2 - 4 } & $18-42$ & $\begin{array}{l}\text { Ryzyko jest tolerowalne, } \\
\text { wymagana dalsza analiza; } \\
\text { możliwy skutek: incydent } \\
\text { lotniczy }\end{array}$ \\
\cline { 3 - 4 } & $1-16$ & $\begin{array}{l}\text { Ryzyko jest akceptowalne } \\
\text { a obecnej postaci, możliwy } \\
\text { skutek: incydent. }\end{array}$ \\
\hline
\end{tabular}


The concept of risk tolerability matrix determination for aeronautical data... Koncepcja wyznaczenia macierzy tolerancji ryzyka dla łańcucha danych...

$\mathrm{W}$ macierzy tolerancji ryzyka $\mathrm{z}$ tabeli 10 wyjaśnienia wymaga jeszcze sprawa nieciągłości przedziałów wartości oceny ryzyka. Dla przykładu obszar akceptowalnych wartości ryzyka jest ograniczony od góry wartością 16, a minimalna wartość dla obszaru ryzyka tolerowalnego to 18 . Można by więc powiedzieć, iż wartość 17 (oraz wartości 43 i 44 dla drugiego punktu granicznego) zostały zgubione. Nie byłoby to jednak stwierdzenie prawdziwe. Ponieważ wartości indeksu oceny ryzyka są wyznaczane jako iloczyn wartości $P$ i $B$ (z zakresu od 1 do 10) nie ma matematycznej możliwości uzyskania wyniku iloczynu równego 17 (jest to liczba pierwsza), ani równego 43 lub 44. Nie jest to więc błąd w opracowanej macierzy tolerancji ryzyka, lecz pewna nieciągłość wynikająca $\mathrm{z}$ faktu, iż niewystępujące $\mathrm{w}$ macierzy oceny ryzyka liczby nie są osiągalne matematycznie przy przyjętych założeniach.

\section{Podsumowanie, wnioski}

W związku z formułą proaktywnego zarządzania bezpieczeństwem, opisaną w [6,9] oraz zidentyfikowaną koniecznością zarządzania niezgodnościami, w artykule zaproponowano koncepcję wyznaczenia macierzy tolerancji ryzyka dla łańcucha danych i informacji lotniczych. Wyznaczono wartości graniczne, rozdzielające 3 poziomy ryzyka, zgodne z [10]: T, A oraz NA.

Opracowane rozwiązanie może stanowić podstawę do przeprowadzenia pełnej analizy ryzyka omawianego zagadnienia problemowego metodą FMEA/FMECA z ilościowym podsumowaniem wyników, wg liczby priorytetu ryzyka - RPN (ang. Risk Priority Number). Wymagać to będzie rozważenia i uwzględnienia parametru wykrywalności niezgodności - $W \mathrm{w}$ analizowanym łańcuchu, ponieważ liczba RPN wyznaczana jest jako iloczyn trzech ocenianych kryteriów: ryzyka/prawdopodobieństwa wystąpienia wady (liczba $P$ ), poziomu wykrywalności niegodności (liczba $W$ ) oraz konsekwencji/skutków wystąpienia wady (liczba $S$ lub zaproponowane $B$ ), lecz przedstawione wartości liczbowe parametrów $P$ i $S / B$ (od 1 do 10 ) są spójne $\mathrm{z}$ wykorzystywanymi w metodzie FMEA. Ponadto wyznaczone granice poziomów ryzyka T, A i NA mogłyby stanowić wartości graniczne dla liczb RPN.

Zagadnienie to będzie przedmiotem dalszych prac autorów.

\section{Literatura}

[1] Dudek E., Kozłowski M.: Koncepcja procesu oceny jakości danych lotniczych, Prace Naukowe Politechniki Warszawskiej - Transport, z. 113, str. 131-140, Warszawa 2016, nr ISSN: 1230-9265. 
[2] Dudek E., Kozłowski M.: Koncepcja zarządzania jakością danych lotniczych, Prace Naukowe Politechniki Warszawskiej - Transport, z. 113, str. 141-150, Warszawa 2016, nr ISSN: 1230-9265.

[3] Dudek E., Kozłowski M.: Koncepcja zastosowania metodyki DMAIC do zapewnienia jakości danych lotniczych, [w] Kwasiborska A. (red.): Transport lotniczy i jego otoczenie, Wydział Transportu Politechniki Warszawskiej, str. 67-78, Warszawa 2016, nr ISBN: 978-83-7814-548-6.

[4] Dudek E., Kozłowski M.: The concept of a method ensuring aeronautical data quality, Journal of KONBiN No 1(37)2016, str. 319-340, Warszawa 2016, nr ISSN: 1895-8281.

[5] Hamrol A., Mantura W., Zarządzanie jakością: teoria i praktyka, Wydawnictwo Naukowe PWN, Warszawa, 2013.

[6] Krajowy Program Bezpieczeństwa w Lotnictwie Cywilnym, Ministerstwo Infrastruktury i Budownictwa, Urząd Lotnictwa Cywilnego, Warszawa, sierpień 2016.

[7] Myszewski J., Po prostu jakość: podręcznik zarząadzania jakością, Wydawnictwa Akademickie i Profesjonalne, Warszawa 2009.

[8] Norma ISO 31010:2010, Risk management - Risk assessment techniques, 2010.

[9] Norma IEC 60812:2006, Analysis techniques for system reliability, Part 2 Procedure for failure mode and effects analysis (FMEA), 2006.

[10] Podręcznik zarządzania bezpieczeństwem (ang. Safety Management Manual SMM) - ICAO Doc. 9859.

[11] Specyfikacja Eurocontrol - Poziomy ufności danych, $\mathrm{nr}$ referencyjny dokumentu: EUROCONTROL-SPEC-0148.

[12] Ustawa z dnia 3 lipca 2002 r. Prawo Lotnicze, Dz. U.2002 Nr 130, poz. 696 z późn. zm.

[13] Załącznik 4 do Konwencji o międzynarodowym lotnictwie cywilnym, Mapy lotnicze, Organizacja Międzynarodowego Lotnictwa Cywilnego, lipiec 2009.

[14] Załącznik 8 do Konwencji o międzynarodowym lotnictwie cywilnym, Zdatność do lotu statków powietrznych, Organizacja Międzynarodowego Lotnictwa Cywilnego, lipiec 2010.

[15] Załącznik 13 do Konwencji o międzynarodowym lotnictwie cywilnym, Badanie wypadków i incydentów statków powietrznych, Organizacja Międzynarodowego Lotnictwa Cywilnego, lipiec 2010. 
The concept of risk tolerability matrix determination for aeronautical data... Koncepcja wyznaczenia macierzy tolerancji ryzyka dla tańcucha danych...

[16] Załącznik 19 do Konwencji o międzynarodowym lotnictwie cywilnym, Zarządzanie Bezpieczeństwem, Organizacja Międzynarodowego Lotnictwa Cywilnego, lipiec 2013.

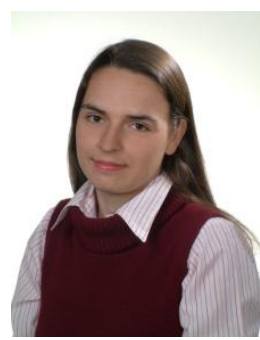

Mgr ini. Ewa Dudek pracuje na stanowisku asystenta w Zaktadzie Telekomunikacji w Transporcie na Wydziale Transportu Politechniki Warszawskiej. Zainteresowania naukowe obejmuja telematykę transportu, integracje systemów, zagadnienia, zwiazane $z$ ruchem lotniczym oraz automatyke procesów ciagtych (Udziat 50\%).

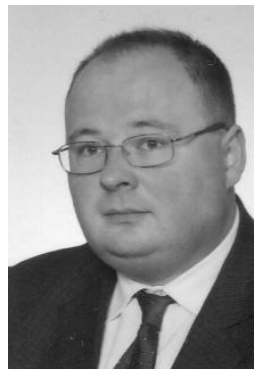

Dr inż. Michat Kozłowski - Adiunkt w Zakładzie Inżynierii Transportu Lotniczego Wydziatu Transportu Politechniki Warszawskiej. Bogate doświadczenie w zakresie zarzadzania portem lotniczym, wyniesione $z$ ponad dwudziestoletniej pracy zawodowej $w$ obszarze operacyjnym Lotniska Chopina $w$ Warszawie. Autor licznych badań, publikacji i wdrożeń, m.in. $z$ zakresu systemów zarzadzania, $w$ tym bezpieczeństwem i przepustowościa (Udział 50\%). 